\title{
PENERAPAN METODE CERTAINTY FACTOR UNTUK DIAGNOSIS PENYAKIT PADA ANAK
}

\author{
Eka Mala Sari Rochman \\ 1) Program Studi Teknik Informatika, Fakultas Teknik, Universitas Trunojoyo \\ Jl Raya Telang, PO. BOX 2, Kamal, Bangkalan \\ Email : ekamala.sari@yahoo.com
}

\begin{abstract}
Abstrak
Kesehatan anak merupakan hal yang patut kita perhatikan serta membutuhkan penanganan tepat, karena hal ini juga tergantung dari kondisi anak tersebut. Namun, seringkali terjadi penanganan yang lambat hal ini dikarenakan terkendala jarak dari rumah ke rumah sakit dan keadaan sosial yang tidak mendukung. Oleh karena itu diperlukan sebuah sistem yang dapat mempermudah proses penanganan penyakit pada anak. Pada penelitian ini bertujuan untuk membangun sebuah sistem diagnosis penyakit anak menggunakan metode Certainty Factor $(C F)$. Metode CF ini merupakan salah satu metode dalam sistem pakar yang mana digunakan untuk memprediksi diagnosis penyakit anak dengan mencocokan data gejala dan penyakit dari para ahli tentunya dalam hal ini adalah dokter anak. Dari hasil pengujian yang telah dilakukan, dapat diketahui bahwa metode CF pada diagnosa penyakit anak menghasilkan akurasi sebesar $80 \%$.
\end{abstract}

Kata kunci: Certainty Factor (CF), diagnosa, penyakit anak, kesehatan.

\begin{abstract}
Children's health is something that we should pay attention to and require proper handling, because this also depends on the child's condition. However, often the handling is slow this is due to constrained distance from home to hospital and social conditions that are not supportive. Therefore we need a system that can simplify the process of handling disease in children. In this study aims to build a diagnosis of childhood diseases using the Certainty Factor $(C F)$ method. This CF method is one of the methods in the expert system which is used to predict the diagnosis of pediatric ailments by matching symptom and disease data from experts, of course, in this case pediatricians. From the results of tests that have been done, it can be seen that the CF method in diagnosing childhood diseases produces an accuracy of $80 \%$.
\end{abstract}

Keywords : Modeling, explosion, serious games, visualization

\section{PENDAHULUAN}

Perkembangan teknologi saat ini telah mengalami banyak perubahan pesat, seiring dengan kebutuhan manusia yang semakin banyak dan kompleks. Komputer kini telah digunakan secara luas di berbagai bidang, misalnya: Bisnis, Kesehatan, Pendidikan, Psikologi, Permainan dan sebagainya. Hal ini mendorong para ahli untuk semakin mengembangkan komputer agar dapat membantu kerja manusia atau bahkan melebihi kemampuan kerja manusia.

Kesehatan merupakan hal yang berharga bagi manusia, karena setiap orang dapat mengalami gangguan kesehatan. Termasuk anak yang dibawah umur lima tahun sangat rentan terhadap kuman penyakit dan kurangnya kepekaan terhadap gejala suatu penyakit, khususnya penyakit yang sering diderita terutama di daerah tropis merupakan ketakutan tersendiri bagi orang tua, yang awam terhadap kesehatan. Apabila terjadi gangguan kesehatan terhadap anak maka mereka lebih mempercayakannya kepada pakar atau dokter ahli yang sudah mengetahui lebih banyak tentang kesehatan, tanpa memperdulikan apakah gangguan tersebut masih dalam tingkat rendah atau kronis. Namun dengan kemudahan adanya para pakar atau dokter ahli, terkadang terdapat pula kelemahannya seperti jam kerja (praktek) terbatas dan banyaknya pasien hingga harus menunggu antrian yang panjang dengan biaya yang tidak sedikit.

Dalam hal ini, orang tua selaku pemakai jasa lebih membutuhkan seorang pakar yang bisa memudahkan dalam mendiagnosa penyakit lebih dini agar dapat melakukan pencegahan lebih 
awal yang sekiranya membutuhkan waktu jika berkonsultasi dengan dokter ahli, biaya yang tidak sedikit, dan jarak tempuh yang memakan waktu. Karena hal tersebut, maka dibutuhkan suatu alat bantu yang dapat mendiagnosa penyakit anak berupa sistem pakar. Salah satu implementasi yang diterapkan sistem pakar dalam bidang psikologi, yaitu untuk sistem pakar menentukan jenis gangguan perkembangan pada anak. Anak-anak merupakan fase yang paling rentan dan sangat perlu diperhatikan satu demi satu tahapan perkembangannya.

Kesehatan terhadap anak-anak adalah suatu yang patut diperhatikan dan juga dibutuhkan penanganan yang tepat tergantung dalam kondisinya [1]. Sehingga kesehatan anak dapat ditangani dan mungkin dapat menyelamatkan nyawa. Oleh karena itu dibutuhkan suatu system dimana system tersebut dapat dijangkau meskipun di tempat dan keadaan yang darurat sehingga dapat ditangani dengan tepat.Prediksi sangat dibutuhkan dengan data dari pakar atau expert yang mengacu pada pembuat sistem tersebut sehingga menghasilkan suatu sistem yang kompleks. Pada penelitian sebelumnya telah dijelaskan membangun aplikasi pakar untuk mendiagnosa penyakit umum yang sering diderita balita, namun perlu disempurnakan lagi pada sistem pendiagnosaanya agar lebih userfriendly.

Masyarakat dengan pengetahuan yang tidak terlalu tinggi mengenai kesehatan tidak dapat mengetahui penyakit secara dini melalui gejala-gejala yang terjadi pada anak. Untuk gejala-gejala penyakit yang tidak terlalu parah mengharuskan orang tua membawa anaknya ke pelayanan kesehatan, sehingga membutuhkan biaya yang lebih. Dengan permasalahan tersebut, diusulkan metode certainty factor untuk mengetahui penyakit pada anak yang terdiri dari demam berdarah, tifoid dan diare sehingga memudahkan orang tua untuk mengetahui diagnosa penyakit sementara pada anak.

\section{DASAR TEORI}

Pada bab ini akan menjelaskan mengenai beberapa penyakit yang sering mucul pada anak serta cara kerja metode $\mathrm{CF}$.

a. Aplikasi Diagnosa Penyakit

Aplikasi diagnosa penyakit merupakan program komputer yang memperlihatkan deraja keahlian tertentu sebanding dengan menggunakan pendapat seorang ppakar atau dokter [2]. Keahlian aplikasi diagnosa penyakit dalam mendiagnosa suatu penyakit diperoleh dengan cara merepresentasikan pengetahuan seorang atau beberapa orang pakar atau dokter dalam format tertentu dan menyimpannya dalam basis pengetahuan. Sistem pakar berbasis kaidah (rule-based expert) adalah sistem pakar yang menggunakan kaidah (rules) untuk merepresentasikan pengetahuan di dalam basis pengetahuannya.

b. Demam Berdarah

Penyakit demam berdarah adalah penyakit infeksi oleh virus Dengue yang ditularkan melalui gigitan nyamuk Aedes, dengan ciri demam tinggi mendadak disertai manifestasi perdarahan dan bertendensi menimbulkan renjatan (shock) dan kematian [3]. Penyakit demam berdarah dipengaruhi oleh kondisi lingkungan, mobilitas penduduk, kepadatan penduduk, adanya kontainer buatan ataupun alami di Tempat Pembuangan Terakhir (TPA) ataupun di tempat sampah lainnya, penyuluhan dan perilaku masyarakat, antara lain: pengetahuan, sikap, kegiatan pemberatasan sarang nyamuk (PSN), fogging, abatisasi, dan pelaksanaan 3M (menguras, menutup dan mengubur). Faktor utama penyakit demam berdarah di Indonesia adalah nyamuk Aedes aegypti. Tempat yang disukai sebagai tempat perindukannya adalah genangan air yang terdapat dalam (kontainer) tempat penampungan air artifisial misalnya drum, bak mandi, gentong, ember dan sebagainya.

\section{c. Tifoid}

Demam Tifoid adalah penyakit yang disebabkan oleh infeksi bakteria Salmonella typhi [4]. Tifoid dapat menular dengan cepat, umumnya melalui konsumsi makanan atau minuman yang sudah terkontaminasi tinja yang mengandung bakteri Salmonella typhii. Pada kasus yang jarang terjadi, penularan tifoid dapat terjadi karena terpapar urine yang sudah terinfeksi bakteri Salmonella typhii.

d. Diare 
Diare adalah penyakit yang membuat penderitanya menjadi sering buang air besar, dengan kondisi tinja yang encer [5]. Pada umumnya, diare terjadi akibat makanan dan minumam yang terpapar virus, bakteri, atau parasit. Penyakit diare disebabkan karena makanan yang terkontaminasi oleh bakteri pathogen seperti bakteri coliform (Escheria coli, Enteribacter arogenes), Shigella spp, salmonella spp, dan Virbrio cholerea. Kontaminasi mikroorganisme pada makanan tersebut disebabkan dari tidak mempraktekkan hygienis perorangan dan tidak mencuci alat masakan dan wadah makanan.

\section{e. Certainty Factor}

Faktor kepastian (certainty factor) diusulkan oleh Shortliffe dan Buchanan pada 1975 untuk mengakomodasikan ketidakpastian pemikiran (inexact reasoning) seorang pakar [6]. Seorang pakar, (misalnya dokter) sering kali menganalisis informasi yang ada dengan ungkapan seperti misalnya : mungkin, kemungkinan, besar, hampir pastin. Untuk mengakomodasi hal ini dengan menggunakan certainty factor (CF) guna menggambarkan tingkat keyakinan pakar terhadap masalah yang dihadapi. Secara umum, rule direpresentasikan dalam bentuk sebagai berikut:

$$
\begin{gathered}
\text { IF E1 [AND / OR] E2 [AND / OR] ... End } \\
\text { THEN H (CF=Cfi })
\end{gathered}
$$

Dimana :

E1 ....En : faktra-faktra (evidence) yang ada

$\mathrm{H}$ : hipotesa atau konklusi yang dihasilkan

$\mathrm{CF}$ : tingkat keyakinan (certainty factor) terjadinya hipotesa akibat adanya fakta-fakta.

Certainty factor adalah suatu metode untuk membuktikan apakah suatu fakta itu pasti ataukah tidak pasti yang berbentuk metric yang biasanya digunakan dalam sistem pakar [6][7][8]. Metode ini sangat cocok untuk sistem pakar yang mendiagnosis sesuatu yang belum pasti. Perumusan nilai CF dapat ditunjukkan pada persamaan (2).

Dimana :

$$
\mathrm{CF}(\mathrm{H}, \mathrm{e})=\mathrm{CF}(\mathrm{E}, \mathrm{e})^{*} \mathrm{CF}(\mathrm{H}, \mathrm{E})
$$

$\mathrm{CF}(\mathrm{H}, \mathrm{e})$ : certainty factor hipotesis yang dipengaruhi oleh evidence e.

$\mathrm{CF}(\mathrm{E}, \mathrm{e}) \quad$ : certainty factor evidence $\mathrm{E}$ yang dipengaruhi oleh evidence e.

$\mathrm{CF}(\mathrm{H}, \mathrm{E}) \quad$ : certainty facotr hipotesis dengan asumsi evidence dikethui dengan pasti, yaitu ketika $\mathrm{CF}(\mathrm{E}, \mathrm{e})=1$. Jika semua evidence pada antecendent diketahui dengan pasti maka persamaanya akan menjadi persamaan pada (3):

$$
\mathrm{CF}(\mathrm{E}, \mathrm{e})=\mathrm{CF}(\mathrm{H}, \mathrm{E})
$$

\section{METODOLOGI PENELITIAN}

a) Data

Data yang digunakan pada penelitian berupa gejala dan penyakit pada anak serta nilai CF masing-masing gejala. Data berasal dari pendapat dari seorang dokter Puskesmas Kamal berdasarkan pengetahuan dan pengalaman dokter tersebut. Data gejala merupakan penyebab beberapa penyakit pada anak. Berikut data yang telah terkumpul ditunjukkan pada tabel 3.1.

Tabel 1. Data Gejala, Nilai CF dan Penyakit pada Anak

\begin{tabular}{|c|l|c|c|c|c|}
\hline \multirow{2}{*}{ No } & \multirow{2}{*}{ Gejala } & \multirow{2}{*}{ CF } & \multicolumn{3}{|c|}{ Penyakit } \\
\cline { 4 - 7 } & & & DBD & Tifoid & Diare \\
\hline 1 & Demam & 0,800 & $\sqrt{ }$ & $\sqrt{ }$ & - \\
\hline 2 & Lesu & 0,730 & $\sqrt{ }$ & $\sqrt{ }$ & $\sqrt{ }$ \\
\hline 3 & Malas makan & 0,750 & $\sqrt{ }$ & $\sqrt{ }$ & - \\
\hline 4 & Pendarahan pada kulit & 0,850 & $\sqrt{ }$ & - & - \\
\hline 5 & Mimisan & 0,500 & $\sqrt{ }$ & - & - \\
\hline 6 & Sakit kepala & 0,750 & $\sqrt{ }$ & $\sqrt{ }$ & - \\
\hline 7 & Tubuh mengigil & 0,500 & $\sqrt{ }$ & $\sqrt{ }$ & - \\
\hline 8 & Denyut jantung lemah & 0,500 & - & $\sqrt{ }$ & - \\
\hline
\end{tabular}




\begin{tabular}{|c|l|c|c|c|c|}
\hline 9 & Badan lemah & 0,800 & $\sqrt{ }$ & $\sqrt{ }$ & - \\
\hline 10 & Nyeri otot myalgia & 0,700 & $\sqrt{ }$ & $\sqrt{ }$ & - \\
\hline 11 & Tidak nafsu makan & 0,800 & $\sqrt{ }$ & $\sqrt{ }$ & - \\
\hline 12 & Konstipasi & 0,300 & $\sqrt{ }$ & - & - \\
\hline 13 & Sakit perut & 0,567 & $\sqrt{ }$ & $\sqrt{ }$ & $\sqrt{ }$ \\
\hline 14 & Nyeri tenggorokan & 0,000 & - & - & - \\
\hline 15 & Hidung meler & 0,000 & - & - & - \\
\hline 16 & Batuk & 0,000 & - & - & - \\
\hline 17 & Bercak koplik & 0,000 & - & - & - \\
\hline 18 & Mata merah & 0,000 & - & - & - \\
\hline 19 & Buang air besar terus-menerus & 0,850 & - & - & $\sqrt{ }$ \\
\hline 20 & Mual & 0,567 & $\sqrt{ }$ & $\sqrt{ }$ & $\sqrt{ }$ \\
\hline 21 & Muntah-muntah & 0,567 & $\sqrt{ }$ & $\sqrt{ }$ & $\sqrt{ }$ \\
\hline 22 & Pegal pada punggung & 0,300 & - & $\sqrt{ }$ & - \\
\hline 23 & Perut sering berbunyi & 0,800 & - & - & $\sqrt{ }$ \\
\hline 24 & Kekakuan rahang & 0,000 & - & - & - \\
\hline 25 & Nyeri telan & 0,000 & - & - & - \\
\hline 26 & Kejang otot & 0,000 & - & - & - \\
\hline 27 & Nyeri perut & 0,450 & $\sqrt{ }$ & - & $\sqrt{ }$ \\
\hline 28 & Nyeri punggung & 0,000 & - & - & - \\
\hline 29 & Tonjolan kemerahan & 0,000 & - & - & - \\
\hline
\end{tabular}

b) Arsitektur Sistem

1) Arsitektur Rancangan Sistem

Terdapat beberapa tahpan yang harus dilakukan pada sistem yang akan dibuat dalam penelitian ini. Beberapa tahapan ini akan dijabarkan pada Gambar Diagram Input Process Output (IPO) berikut.

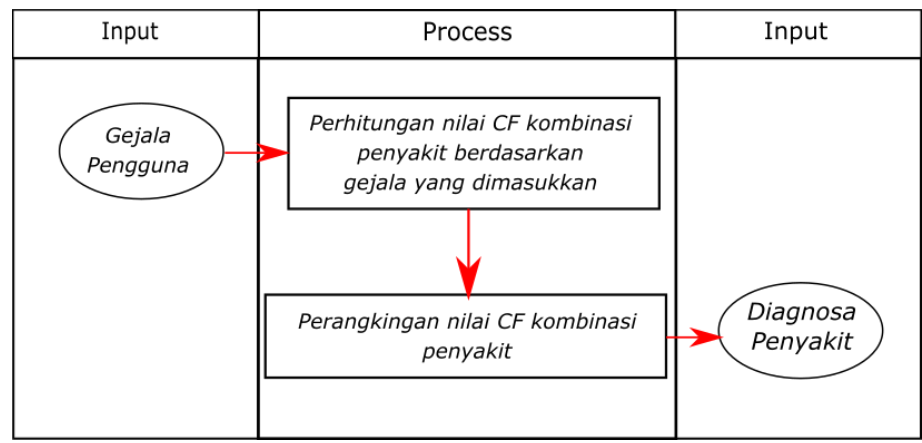

Gambar 1. Diagram Input, Process and Output (IPO)

Pada Gambar 1 Diagram IPO dimulai dengan pengguna memasukan gejala yang terjadi pada dirinya. Selanjutnya perhitungan nilai CF kombinasi penyakit berdasarkan gejala yang dimasukkan. Lalu, perangkingan nilai CF kombinasi penyakit dan penyakit yang memiliki nilai $\mathrm{CF}$ tertinggi merupakan hasil penyakit anak.

2) Algoritma Sistem

Pada algoritma sistem untuk penelitian ini berisikan flowchart gambaran umum alur sistem aplikasi diagnosa penyakit anak menggunakan certainty factor yang akan dibuat. Flowchart untuk sistem ini ditunjukan pada Gambar 2. 


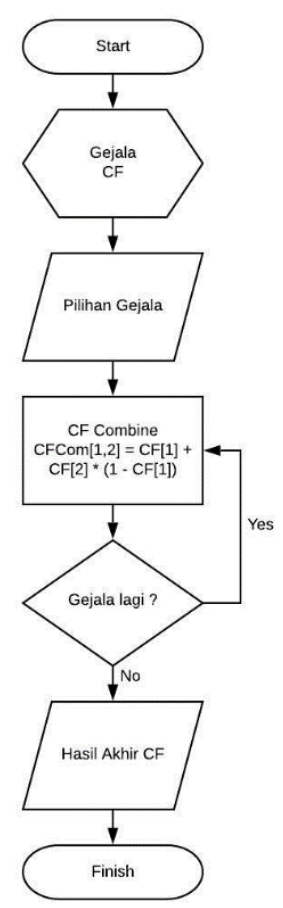

Gambar 2. Flowchart Aplikasi Diagnosa Penyakit pada Anak

Pada Gambar 2. dimulai dengan pengguna memasukan gejala yang terjadi pada dirinya. Selanjutnya perhitungan nilai CF kombinasi penyakit berdasarkan gejala yang dimasukkan. Lalu, perangkingan nilai $\mathrm{CF}$ kombinasi penyakit dan penyakit yang memiliki nilai $\mathrm{CF}$ tertinggi merupakan hasil penyakit anak.

3) Use Case

Use case pada aplikasi diagnosa penyakit anak menggunakan metode certainty factor ditunjukkan pada Gambar 3.

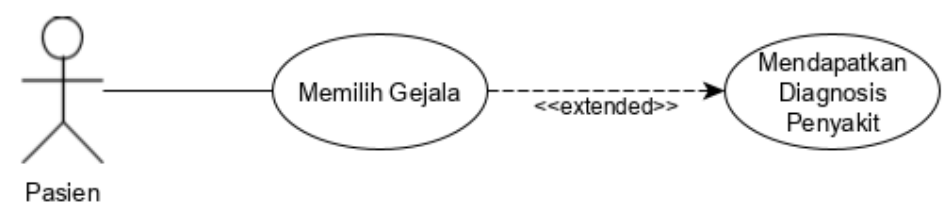

Gambar 3. Use Case Aplikasi Diagnosa Penyakit pada Anak

Pada Gambar 3 pengguna atau lebih spesifik adalah pasien dapat memilih gejala-gejala yang terjadi. Selanjutnya, pengguna mendapat informasi penyakit yang terjadi berdasarkan gejala yang telah dipilih.

\section{HASIL DAN PEMBAHASAN}

Antarmuka aplikasi merupakan tampilan aplikasi diagnosa penyakit pada anak menggunakan metode certainty factor yang berhubungan secara langsung dengan pengguna/pasien. Antarmuka aplikasi dibuat untuk memudahkan pasien untuk menggunakan aplikasi. Tampilan antarmuka pada aplikasi yang dibuat terdiri dari halaman utama dan halaman hasil diagnosa. 


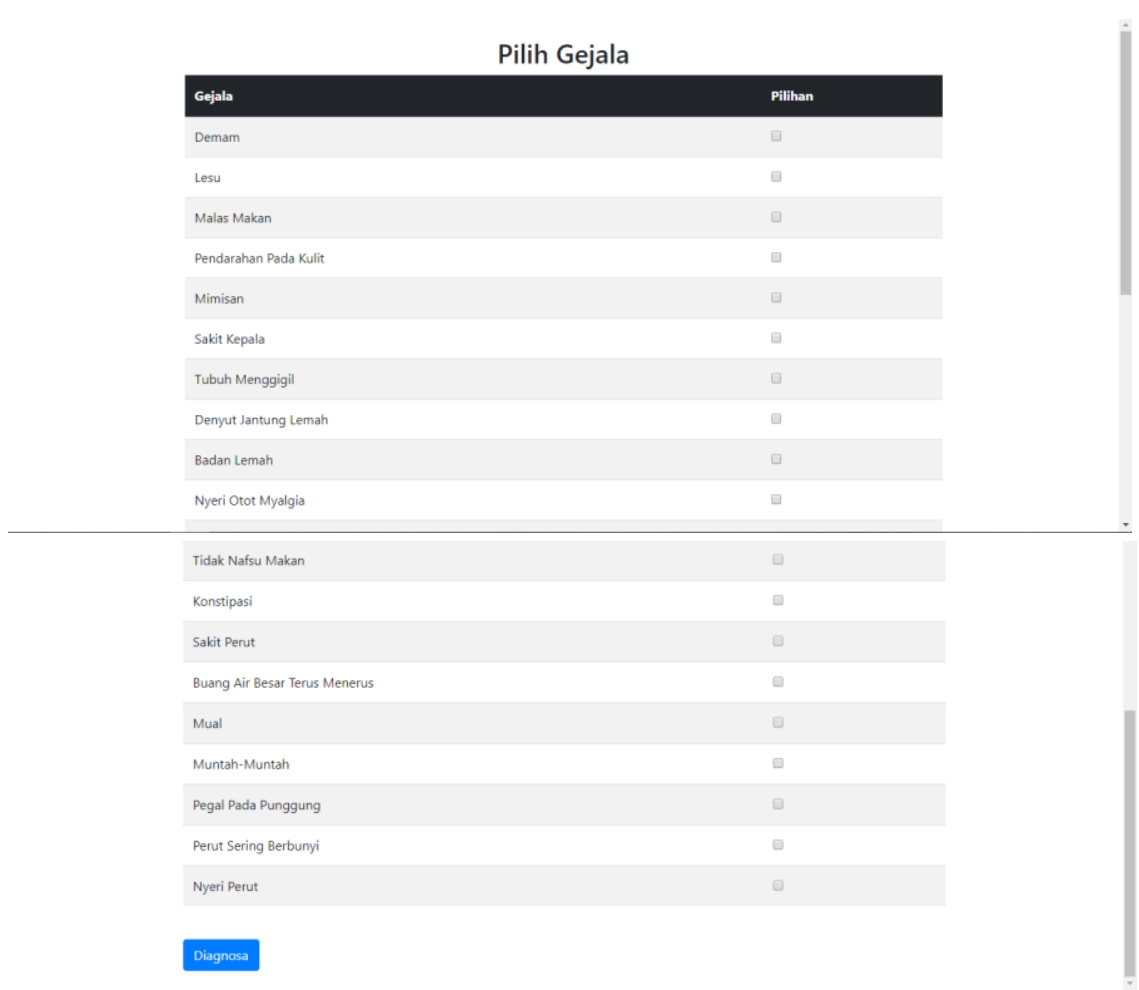

Gambar 4. Tampilan Halaman Utama

\section{Pilih Gejala}

\begin{tabular}{|l|l|}
\hline Gejala & Pilihan \\
\hline Demam & \\
\hline Lesu & \\
\hline Malas Makan & \\
\hline Pendarahan Pada Kulit & $\square$ \\
\hline Mimisan & \\
\hline
\end{tabular}

Gambar 5. Tampilan pemilihan gejala

Hasil Diagnosa

\begin{tabular}{|c|c|}
\hline Nilai Kepastian & 0.99375 \\
\hline Solusi & $\begin{array}{l}\text { 1. Banyak minum cairan, seperti air, susu, jus buah-buahan } \\
\text { 2. Minum obat pereda nyeri, seperti Paracetamol } \\
\text { 3. Infus cairan } \\
\text { 4. Istirahat cukup }\end{array}$ \\
\hline
\end{tabular}

Dan kemungkinan penyakit lain yang menyerang anda adalah :

\begin{tabular}{|ll}
\hline Penyakit & Nilai Kepastian \\
\hline Tifoid & 0.9875 \\
\hline Diare & 0 \\
\hline
\end{tabular}

Back

Gambar 6. Tampilan halaman hasil diagnosa penyakit demam berdarah 


\begin{tabular}{|l|l|l|l|l|}
\hline 8 & $\begin{array}{l}\text { Kejang otot, nyeri perut, badan } \\
\text { lemah, dan malas makan }\end{array}$ & Tifoid & Tifoid & Tepat \\
\hline 9 & $\begin{array}{l}\text { Lesu, sakit perut, mual dan muntah- } \\
\text { muntah }\end{array}$ & DBD & Diare & $\begin{array}{l}\text { Tidak } \\
\text { Tepat }\end{array}$ \\
\hline 10 & $\begin{array}{l}\text { Pegal pada punggung, denyut } \\
\text { jantung lemah, demam, dan malas } \\
\text { makan }\end{array}$ & Tifoid & Tifoid & Tepat \\
\hline
\end{tabular}

Pada Tabel 2 merupakan skenario pengujian dan perbandingan hasil penyakit dari aplikasi dengan penyakit dari dokter berdasarkan gejala-gejala masukan yang sama. Terlihat akurasi aplikasi sebanyak 8 hasil penyakit dari aplikasi yang sama dengan hasil penyakit dari dokter dari 10 uji coba. Jadi, akurasi aplikasi diagnosa penyakit pada anak menggunakan metode certainty factor sebesar $80 \%$.

\section{KESIMPULAN}

Dari hasil pembahasan diatas dapat disimpulkan bahwa aplikasi sistem pakar ini dapat mendiagnosa penyakit anak yang sering diderita berdasarkan gejala yang dialami, sistem ini juga dapat memberikan informasi penyakit tersebut beserta solusinya. Dengan diberikan interface yang user friendly maka aplikasi sistem pakar ini dapat mudah dipelajari dan digunakan untuk kalangan orang awam, sehingga dapat mempermudah dalam mendiagnosa penyakit anak. Hasil akurasi pada aplikasi diagnosa penyakit pada anak menggunakan metode certainty factor ini adalah sebesar $80 \%$.

\section{Daftar Pustaka}

[1] E. Dewi, S. Mulyani, and I. N. Restianie, "Aplikasi Sistem Pakar Untuk Mendiagnosa Penyakit Anak (Balita) Dengan Menggunakan metode Forward Chaining," vol. 1, no. 1, pp. 6-7, 2012.

[2] T. Harihayati and L. Kurnia, "Sistem Pakar Mendiagnosa Penyakit Umum Yang Sering Diderita Balita Berbasis Web Di Dinas Kesehatan Kota Bandung," 2012.

[3] C. Wahyuni, S. Keman, and F. Fathi, "Peran Faktor Lingkungan dan Perilaku terhadap Penularan Demam Berdarah Dengue di Kota Mataram," J. Kesehat. Lingkung. Unair, vol. 2, no. 1, pp. 1-11, 2005.

[4] R. Rismarini, Z. Anwar, and A. Merdjani, "Perbandingan Efektifitas Klinis antara Kloramfenikol dan Tiamfenikol dalam Pengobatan Demam Tifoid pada Anak," Sari Pediatr., vol. 3, no. 2, p. 83, 2016.

[5] R. N. Kurniawan. K and A. Yani, "Persepsi Masyarakat Terhadap Kerentanan Penyakit Diare Pasca Pelaksanaan Pesta Adat Kiki Sapu Dan Hambatan Terhadap Pencegahannya," MPPKI (Media Publ. Promosi Kesehat. Indones. Indones. J. Heal. Promot., vol. 1, no. 2, pp. 58-62, 2018.

[6] N. A. Hasibuan, H. Sunandar, S. Alas, and S. Suginam, "Sistem Pakar Mendiagnosa Penyakit Kaki Gajah Menggunakan Metode Certainty Factor," Jurasik (Jurnal Ris. Sist. Inf. dan Tek. Inform., vol. 2, no. 1, p. 29, 2017.

[7] W. U. Setiabudi, E. Sugiharti, and F. Y. Arini, "Expert System Diagnosis Dental Disease Using Certainty Factor Method,” Sci. J. Informatics, vol. 4, no. 1, pp. 43-50, 2017.

[8] M. Arifin, W. Eka, and Y. Retnani, "Penerapan Metode Certainty Factor Untuk Sistem Pakar Diagnosis Hama Dan Penyakit Pada Tanaman Tembakau."

[9] H. T. Sihotang, "Sistem Pakar Mendiagnosa Penyakit Kolesterol Pada Remaja Dengan Metode Certainty Factor (Cf) Berbasis Web," J. Mantik Penusa, vol. 15, no. 1, pp. 1623, 2014. 